\title{
REPRESENTASI MASKULINITAS MODERN LAKI-LAKI JEPANG \\ DALAM FILM PERFECT WORLD \\ BERDASARKAN SEMIOTIKA BARTHES
}

\author{
Fajria Noviana \\ fajria.noviana@live.undip.ac.id \\ Universitas Diponegoro
}

\begin{abstract}
This paper aims to provide an overview of the concept of masculinity in Japanese society today, which is represented by the main character in "Perfect World" film. The concept of masculinity here is limited to the male main character's masculinity with a disability, considering that people with disabilities are often seen and treated as second-class citizens by the surrounding community. The method used is the semiotic method of Barthes because it provides an interpretation of a sign into language and sees signs from the ideological side of a culture. Furthermore, Chafetz's concept of masculinity is also used as a reference for assessing the masculinity of the main character. As a result, it was found that a man with a disability can still be said to be masculine, whether in traditional or modern concepts. In addition, it can be said that the impermanence of the concept of masculinity is greatly influenced by time and the supporting society in which the concept was born. Men with disabilities can still be masculine as long as most of their masculinity assessment points are still fulfilled. On the other hand, a man without physical limitations can be non-masculine if he cannot meet his masculinity assessment points.
\end{abstract}

Keywords: gender, semiotics, masculinity, difabel, Barthes

Film adalah salah satu dari sekian banyak wujud karya sastra yang sudah akrab dengan kehidupan manusia. Film merupakan hasil dari sebuah konstruksi realitas yang dibangun ulang dengan berbagai proses kreatifnya, untuk menghasilkan audio dan tampilan visual yang dapat dinikmati oleh pemirsa. Konstruksi realitas yang dimaksud adalah kondisi suatu masyarakat yang menjadi latar dari sebuah film, karena karya sastra; dalam hal ini adalah film; banyak merekam realitas dan fenomena yang tumbuh dan berkembang di masyarakat.

Salah satu fenomena yang cukup banyak diangkat menjadi film adalah mengenai isu gender dan jenis kelamin. Hal-hal yang berkelindan dengan gender dan jenis kelamin merupakan isu yang tidak akan pernah berhenti bergulir karena dua hal ini selalu mengalami perubahan dan perkembangan. Sebagai contoh, beberapa tahun yang 
lalu orang hanya dihadapkan pada dua pilihan jenis kelamin saat mengisi formulir, yang biasanya dituliskan dengan L/P atau M/F. Namun sekarang, pilihan menjadi lebih banyak dengan adanya tambahan jenis kelamin ketiga, yang biasanya dituliskan dengan L/P/Lainnya atau M/F/Other.

Gender sering dianggap sama artinya dengan jenis kelamin. Namun, gender sebenarnya mengacu pada sifat yang melekat pada laki-laki dan perempuan yang dikonstruksikan secara sosial dan budaya (Fakih, 2013). Kata konstruksi sosial dan budaya menunjukkan bahwa gender bukanlah sesuatu yang sifatnya alamiah dan tetap, namun diproduksi oleh masyarakat. Oleh karena itu, konsep gender menjadi berbedabeda tergantung masyarakat yang memproduksinya. Dengan demikian, studi gender menjadi sebuah studi yang ditekankan pada perkembangan aspek maskulinitas dan femininitas secara sosial budaya. Perkembangan aspek maskulinitas dan femininitas ini berpengaruh pada banyak hal dalam kehidupan seseorang, misalnya harapan hidup, seksualitas, kebebasan, hubungan sosial, akses terhadap fasilitas publik seperti pendidikan, pekerjaan, dan lain-lain (Noviana \& Wulandari, 2017).

Maskulinitas dan femininitas bagi sebagian orang dianggap berada pada dua kutub yang berbeda. Hal ini membuat asumsi bahwa semakin maskulin seseorang, maka akan semakin berkurang sifat femininnya, demikian pula sebaliknya. Oleh karena itu, laki-laki yang menunjukkan ciri feminin seperti sifat pengasuhan, kelembutan, dan emosionalitas sering dianggap kurang maskulin dibandingkan dengan laki-laki pada umumnya (Rathus, Nevid, \& Fichner-Rathus, 2014). Anggapan ini disanggah oleh Bem yang dalam penelitiannya menemukan bahwa seseorang yang sangat maskulin dimungkinkan untuk memiliki beberapa ciri feminin, dan berlaku sebaliknya (DiDonato \& Berenbaum, 2011).

Konsep maskulinitas dan femininitas terus berubah dan berkembang seiring dengan perkembangan zaman. Maskulinitas tradisional yang berlaku di banyak budaya umumnya identik dengan fisik yang gagah dan kuat, pekerja keras, breadwinner, dan seterusnya. Sementara, maskulinitas tradisional Jepang direpresentasikan melalui kaum 
Fajria Noviana, Representasi Maskulinitas Modern Laki-Laki Jepang dalam Film Perfect World Berdasarkan Semiotika Barthes

samurai pada zaman keshogunan dan salaryman pada sekitar tahun 1960-1980, dan oyaji 'ayah' (Amalia, 2020).

Di Jepang, akhir-akhir ini muncul wacana familyman sebagai pengganti dari salaryman yang merupakan representasi bagi maskulinitas hegemonik. Salaryman di Jepang selama ini dianggap sebagai representasi bagi maskulinitas hegemonik karena identik dengan laki-laki berpendidikan tinggi, berpenghasilan tinggi, dan berstatus sosial tinggi. Sementara, familyman sebagai representasi dari maskulinitas modern tidak hanya menganggap laki-laki sebagai pencari nafkah yang berpendidikan tinggi, namun juga ikut berperan dalam urusan rumah tangga dan keluarga seperti memasak, mengasuh anak, dan lain-lain (McLelland, 2003).

Pergeseran konsep maskulinitas dalam budaya Jepang ini dikaji melalui film berjudul Perfect World, dengan difokuskan pada laki-laki difabel. Pemusatan perhatian pada maskulinitas laki-laki difabel ini perlu dilakukan, karena masyarakat umumnya menganggap mereka sebagai warga kelas dua, tiga, atau bahkan lebih karena keterbatasan fisik mereka.

Penelitian mengenai maskulinitas yang sejenis dengan tulisan ini salah satunya adalah tesis tahun 2014 milik Poedjianto. Dalam tesisnya, Poedjianto menyimpulkan bahwa laki-laki infertil dalam film berjudul Test Pack karya Ninit Yunita masih tetap dapat dikatakan maskulin (2014). Ia menggunakan konsep maskulinitas dari Janet Saltzman Chafetz dalam analisisnya untuk mencari tahu apakah laki-laki infertil dapat dikatakan maskulin, sama dengan konsep maskulinitas yang digunakan dalam tulisan ini.

Penelitian berikutnya adalah artikel jurnal Inklusi tahun 2015 milik Yusuf. Dalam artikelnya, Yusuf mengemukakan bahwa kritik sosial yang dilakukan oleh Seno Gumira Ajidarma sebagai penulis novel Biola Tak Berdawai yang diangkat menjadi film ini adalah sebuah pendobrakan, pembaharuan, dan perlawanan terhadap realitas yang menimpa kaum difabel (2015). Yusuf menyimpulkan bahwa tiap manusia sebagai mahkluk ciptaan Tuhan memiliki kelebihan, kekurangan, dan keindahannya masing- 
masing, termasuk difabel. Difabel dalam artikel ini menjadi fokus penelitian yang berkaitan dengan kritik sosial, sedangkan dalam tulisan ini dijadikan sebagai fokus penelitian mengenai konsep maskulinitas.

Konsep maskulinitas yang dikaji dalam tulisan ini tidak hanya mengkaji aspek maskulinitas laki-laki, namun difokuskan pada aspek maskulinitas modern yang lebih kontemporer. Selain itu, aspek maskulinitas modern yang dikaji difokuskan pada lakilaki difabel.

\section{METODE PENELITIAN}

Penelitian ini berjenis deskriptif kualitatif dengan menggunakan ancangan semiotika Barthes. Semiotika Barthes dipilih karena tidak hanya memberikan interpretasi atas suatu tanda ke dalam bahasa, namun juga melihat tanda dari sisi ideologi yang terdapat dalam suatu budaya (Sobur, 2016). Dapat dikatakan bahwa semiotika Barthes ini lebih fleksibel karena dapat diaplikasikan pada karya visual seperti iklan atau film; tidak hanya pada bahasa seperti umumnya teori semiotika lain (Budiman, 2011).

Sumber data utama penelitian ini berasal dari film Jepang berjudul Perfect World. Film yang merupakan hasil adaptasi manga 'komik Jepang' karya Rie Aruga ini dirilis tahun 2018 dan disutradarai oleh Kenji Shibayama. Film bergenre drama ini dianggap dapat mewakili problematika kehidupan difabel, khususnya yang berkaitan dengan pekerjaan dan tanggung jawab. Laki-laki difabel yang menjadi pusat penceritaan film ini bernama Ayukawa Itsuki, yang mengalami kelumpuhan pada kedua kakinya akibat kecelakaan.

Data yang diambil dari film ini berupa kejadian, objek, dan aktifitas, khususnya yang berkaitan dengan tokoh utama laki-laki bernama Ayukawa Itsuki dan tokoh utama perempuan bernama Kawana Tsugumi. Interaksi dan hubungan antara kedua tokoh inilah yang menjadi pusat penceritaan film. 
Fajria Noviana, Representasi Maskulinitas Modern Laki-Laki Jepang dalam Film Perfect World Berdasarkan Semiotika Barthes

Data berupa kejadian, objek, dan aktifitas yang terkumpul kemudian diklasifikasikan ke dalam tiga tahapan semiotika Barthes, yaitu denotasi, konotasi, dan mitos. Setelah itu, dilakukan analisis untuk mengidentifikasi tanda-tanda maskulinitas pada tokoh utama laki-laki sebagai seorang difabel dengan didasarkan pada tujuh konsep area maskulinitas dalam masyarakat menurut Chafetz (1978) dengan dukungan konsep maskulinitas tradisional dari Roberson, Brod dan Kaufman, serta Siegel dan Meunier, serta konsep maskulinitas modern dari McLelland dan Schroeder.

\section{HASIL DAN PEMBAHASAN}

Pada subbab ini disajikan temuan berupa tanda-tanda maskulinitas pada tokoh utama laki-laki difabel bernama Ayukawa Itsuki, yang disajikan dalam bentuk tabel dengan disertai pembahasan.

\section{Area Penampilan Fisik}

Poin pertama dari konsep ini adalah area penampilan fisik, yang meliputi hal-hal yang berhubungan dengan sifat jantan, atletis, kuat, berani, serta tidak peduli pada penampilan dan proses penuaan (Chafetz, 1978).

\section{Tabel 1. Area Penampilan Fisik}

$\left.\begin{array}{|c|c|}\hline \multicolumn{2}{|c|}{\text { Gemar berolahraga merupakan salah satu ciri pembentuk maskulinitas }} \\ \hline \begin{array}{l}\text { Subuh atletis, rambut pendek, wajah tampan, sering mengenakan } \\ \text { kemeja lengan panjang yang digulung sampai siku saat di luar kantor } \\ \text { SIGN 1 : Signifier } 2\end{array} & \begin{array}{l}\text { Gemar berolahraga, kuat, } \\ \text { jantan, berpenampilan kasual } \\ \text { Signified 2 }\end{array} \\ \hline \text { Signifier } 1 & \begin{array}{l}\text { Tubuh atletis, rambut pendek, } \\ \text { wajah tampan, sering } \\ \text { mengenakan kemeja lengan } \\ \text { panjang yang digulung sampai } \\ \text { siku saat di luar kantor }\end{array} \\ \hline\end{array}\right\}$ Sarthes

Denotasi penampilan fisik maskulin terlihat dari tubuh Ayukawa yang atletis, berambut pendek, berwajah tampan, dan sering mengenakan kemeja lengan panjang 
yang digulung sampai siku. Konotasi penampilan maskulin dapat dilihat pada kegemarannya berolahraga basket, berfisik kuat, jantan, dan berpenampilan kasual. Sementara, mitos tentang maskulinitas terlihat dari kegemarannya berolahraga yang menjadi salah satu ciri pembentuk maskulinitas laki-laki (Huggins, 2012).

Di lain pihak, wajah tampan dan penampilan kasual namun modis Ayukawa merujuk pada maskulinitas modern mengenai male beauty, berbeda dari generasi sebelumnya yang sama sekali tidak mempedulikan keindahan fisik. Hal ini didasarkan pada pernyataan Miller sebagai berikut.

"Previous generations were evaluated primarily on the basis of character, social standing, earning capacity, lineage and other social criteria...[but] young men these days are increasingly concerned with their status as objects of aesthetic and sexual appraisal." (McLelland, 2003, p. 37)

\section{Area Fungsional}

Poin kedua dari konsep ini adalah area fungsional laki-laki, yang meliputi peran laki-laki sebagai tulang punggung keluarga, pencari nafkah, serta penyedia kebutuhan diri dan keluarga (Chafetz, 1978).

\section{Tabel 2. Area Fungsional}

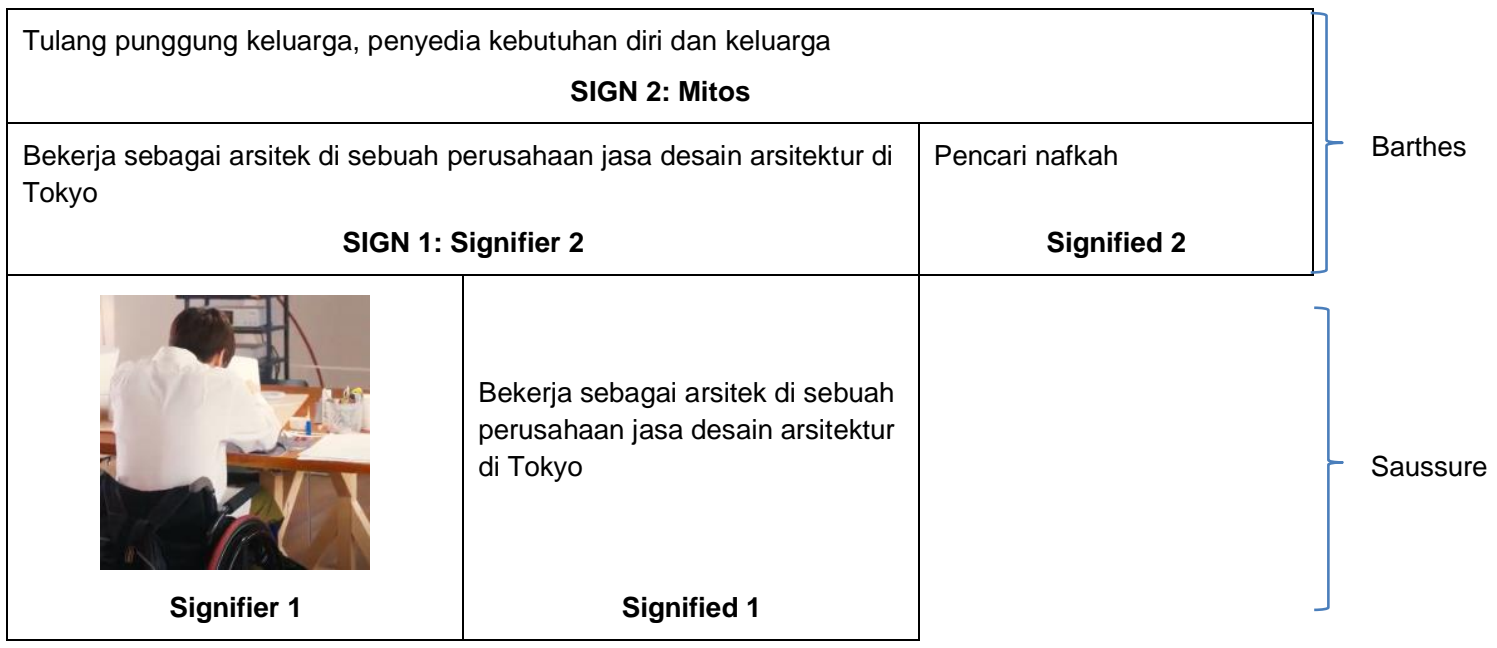

Denotasi fungsional laki-laki maskulin terlihat dari aktifitas Ayukawa yang sedang sibuk mengerjakan maket bangunan pusat kegiatan masyarakat distrik 
Fajria Noviana, Representasi Maskulinitas Modern Laki-Laki Jepang dalam Film Perfect World Berdasarkan Semiotika Barthes

Sakuragaoka. Ia bekerja sebagai seorang arsitek papan atas di salah satu perusahaan jasa desain arsitektur di Tokyo. Konotasi fungsional laki-laki maskulin sebagai pencari nafkah diketahui dari aktifitas Ayukawa yang bekerja di sebuah perusahaan di Tokyo. Sementara, mitos tentang maskulinitas laki-laki secara fungsional merujuk pada anggapan bahwa laki-laki sebagai pencari nafkah utama dalam keluarga memiliki peran sebagai tulang punggung keluarga serta penyedia segala kebutuhan bagi dirinya sendiri dan keluarganya.

Masyarakat sebagai pemilik mitos pada umumnya masih beranggapan bahwa orang yang berprofesi sebagai arsitek memiliki penghasilan di atas rata-rata, sehingga dapat dianggap sebagai golongan ekonomi menengah ke atas. Hal ini selaras dengan poin pertama dari lima anggapan tradisional masyarakat mengenai laki-laki seperti yang dikemukakan oleh Brod dan Kaufman (1994), serta ukuran maskulinitas menurut Demartoto (2010). Kelima anggapan tersebut yaitu: 1) laki-laki seharusnya menjadikan kesuksesan dalam pekerjaan sebagai tujuan utama, sehingga ia mendapat kehormatan dari orang lain dan berpenghasilan tinggi untuk memenuhi kebutuhan keluarganya; 2) laki-laki tidak boleh menyerah, harus rasional, percaya diri, dan mandiri; 3) laki-laki tidak boleh mengeluh dan terlihat lemah, tidak boleh memperlihatkan kekhawatiran, serta harus kuat secara fisik dan psikis; 4) laki-laki harus bersifat agresif dan keras, menikmati bahaya, dan siap berkelahi; 5) laki-laki tidak boleh melakukan kegiatan feminin seperti bekerja di ranah domestik atau memiliki profesi yang umumnya ditekuni perempuan, atau menangis (Brod \& Kaufman, 1994). Sementara, Demartoto secara ringkas menyebutkan bahwa maskulinitas dapat diukur dari kesuksesan, kekuasaan, dan pengaguman dari orang lain. Dengan kata lain, seseorang harus mempunyai kekayaan, ketenaran, dan status yang sangat laki-laki untuk dapat disebut maskulin (Demartoto, 2010).

\section{Area Seksual}

Poin ketiga dari konsep ini adalah area seksual laki-laki. Yang termasuk di dalam poin ini adalah memiliki pengalaman dalam hal berhubungan dekat dengan perempuan 
yang mengarah pada hal-hal yang bersifat seksual dan agresif secara seksual (Chafetz, 1978).

Tabel 3. Area Seksual

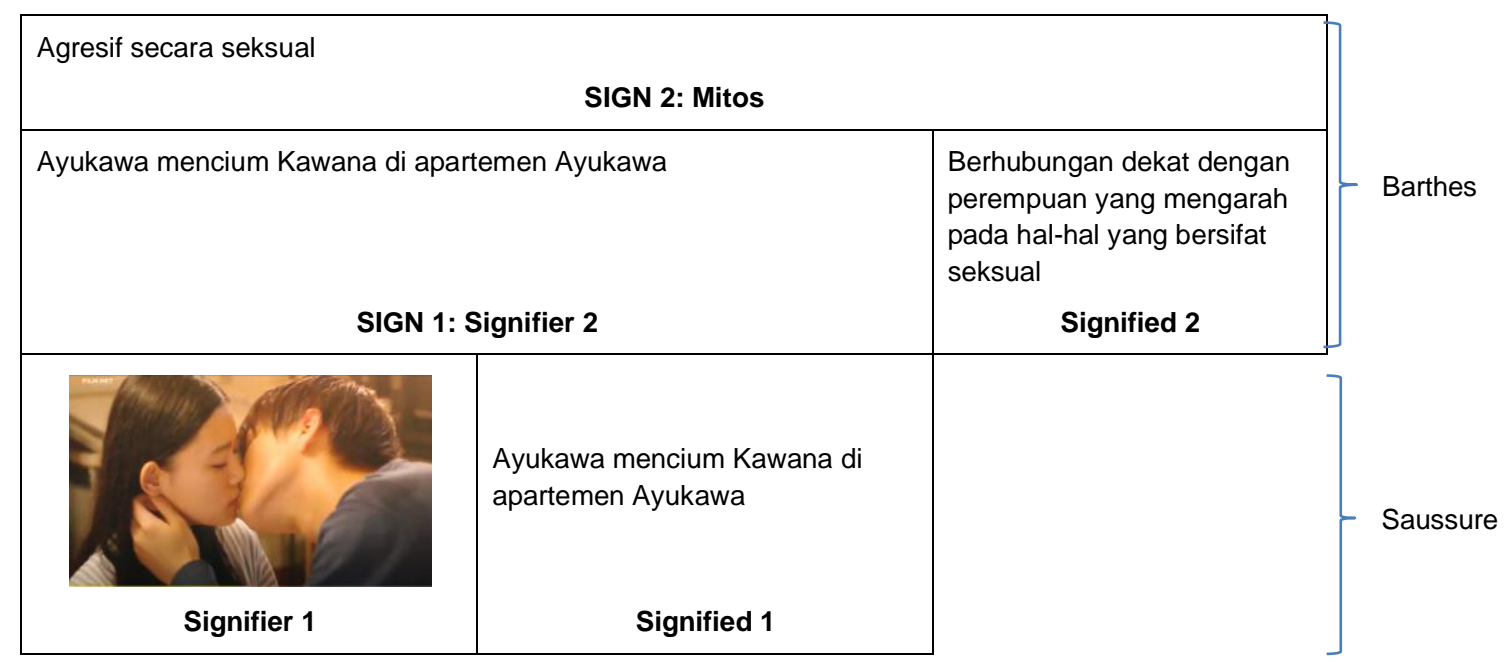

Denotasi seksualitas maskulin Ayukawa terlihat saat ia mencium Kawana. Konotasi yang ditimbulkan adalah adanya hubungan dekat antara Ayukawa dengan Kawana yang mengarah pada hal-hal yang bersifat seksual. Sementara, mitos mengenai maskulinitas terlihat dari stereotip tradisional yang dikemukakan oleh Siegel dan Meunier (2019), yang sebagiannya telah terpenuhi dalam diri tokoh utama laki-laki. Stereotip maskulinitas tradisional tersebut mengasosiasikan kejantanan dan maskulinitas dengan ketegasan, agresifitas, petualangan seksual, dan pengekangan emosional (Siegel \& Meunier, 2019).

Meskipun memenuhi stereotip maskulinitas tradisional menurut Siegel dan Meunier, namun Ayukawa pun menunjukkan kecenderungan yang bertentangan dengan maskulinitas tradisional Jepang seperti yang dikemukakan oleh Roberson (Ruspini, Hearn, Pease, \& Pringle, 2011). Menurut Roberson, maskulinitas tradisional Jepang cenderung ke arah superioritas, kekuasaan, dan posesif; tiga hal yang tidak dilakukan oleh Ayukawa terhadap rekan kerja dan kekasihnya. 
Fajria Noviana, Representasi Maskulinitas Modern Laki-Laki Jepang dalam Film Perfect World Berdasarkan Semiotika Barthes

\section{Area Emosional}

Poin keempat dari konsep ini adalah area emosional, yang menyatakan bahwa laki-laki harus mampu menyembunyikan dan mengendalikan emosi. Dengan kata lain, laki-laki maskulin dituntut untuk tidak emosional dan selalu tenang (Chafetz, 1978).

\section{Tabel 4. Area Emosional}

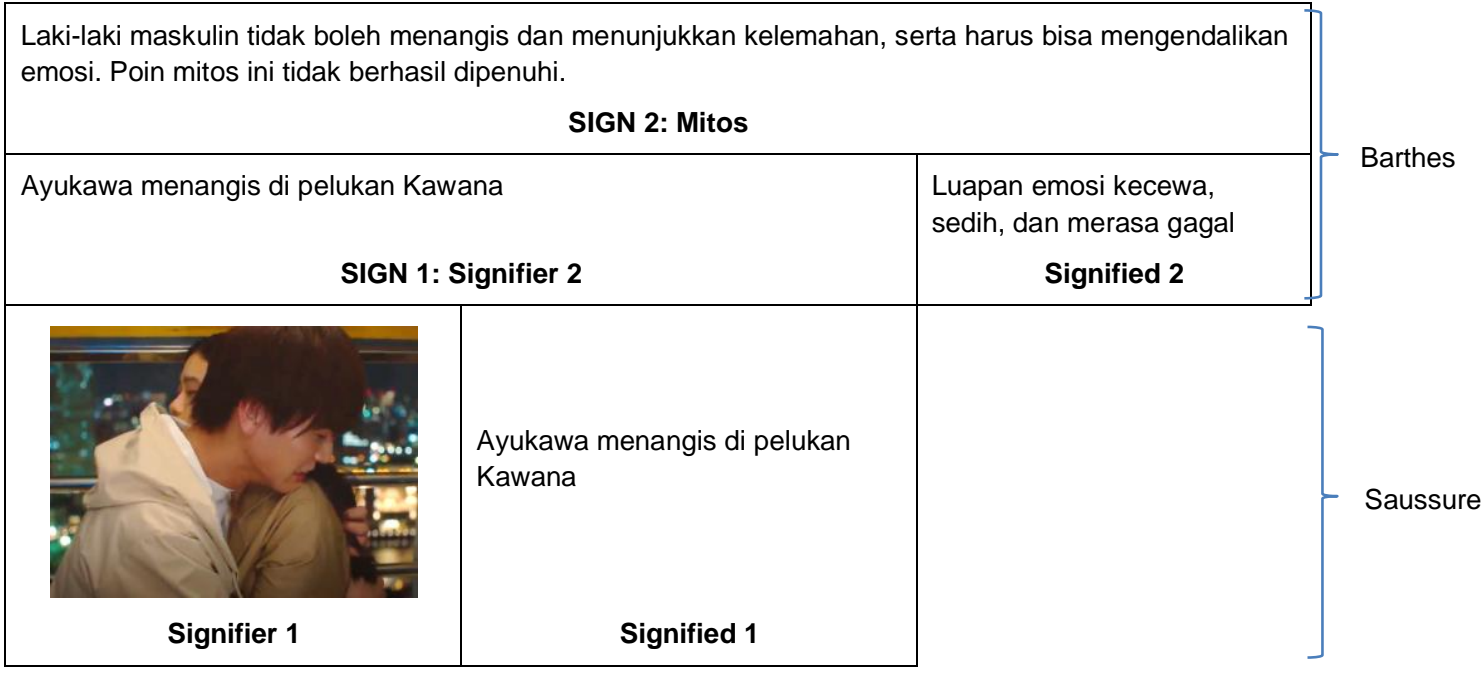

Konsep maskulinitas tradisional melarang laki-laki untuk menunjukkan kelemahan dan harus bisa mengendalikan emosi, terutama di hadapan orang lain, jika laki-laki tersebut ingin dianggap maskulin. Oleh karena itu, denotasi maskulinitas emosional tidak berhasil dipenuhi oleh Ayukawa. Ia menangis di pelukan Kawana saat mengakui segala kekecewaan yang ia rasakan karena merasa gagal dalam membahagiakan dan melindungi kekasihnya. Pengakuan ini menegaskan konotasi kekecewaan, kesedihan, dan perasaan gagal yang diluapkan oleh Ayukawa di hadapan Kawana. Dengan demikian, mitos maskulinitas laki-laki dalam area emosional pun tidak berhasil dipenuhi oleh tokoh utama.

Selain bertentangan dengan konsep maskulinitas Chafetz (1978) serta Siegel dan Meunier (2019), apa yang dilakukan oleh tokoh utama ini juga bertentangan dengan konsep maskulinitas hegemonik. Konsep ini menyatakan bahwa laki-laki tidak boleh menunjukkan kelemahannya karena dapat mempengaruhi kepemimpinan dan dominasinya terhadap perempuan (Connell \& Messerschmidt, 2005). Meskipun 
demikian, sebagai seorang difabel, tokoh utama memang memiliki perasaan yang lebih sensitif dibandingkan dengan laki-laki normal pada umumnya, sehingga ia tidak mampu memenuhi area emosionalnya. Hal ini dikuatkan oleh pernyataan Irwanto yang mengemukakan bahwa disabilitas merupakan sebuah konstruksi yang digunakan untuk mengevaluasi tingkat fungsionalitas manusia, karena difabel diciptakan sebagai pribadi yang berbeda, baik dari segi fisik, kecerdasan, maupun emosionalitasnya (Yusuf, 2015).

Meskipun tidak memenuhi konsep maskulinitas tradisional yang hegemonik, namun yang dilakukan Ayukawa justru sejalan dengan maskulinitas modern yang diciptakan ulang oleh kaum milenial. Dalam salah satu poinnya, maskulinitas modern menerima dan merangkul kerentanan laki-laki sebagai ekspresi keberanian (Schroeder, 2017). Hal inilah yang ditunjukkan oleh tokoh utama saat ia menangis di pelukan kekasihnya.

\section{Area Intelektual}

Poin kelima dari konsep ini adalah area intelektual yang meliputi hal-hal yang berhubungan dengan intelektualitas, pemikiran yang logis, rasional, objektif, dan praktis (Chafetz, 1978). 
Fajria Noviana, Representasi Maskulinitas Modern Laki-Laki Jepang dalam Film Perfect World Berdasarkan Semiotika Barthes

Tabel 5. Area Intelektual

\begin{tabular}{|c|c|c|}
\hline \multicolumn{2}{|c|}{$\begin{array}{l}\text { Laki-laki yang sukses pasti cerdas dan memiliki pemikiran yang logis serta rasional } \\
\qquad \text { SIGN 2: Mitos }\end{array}$} & \multirow[b]{2}{*}{ Barthes } \\
\hline $\begin{array}{l}\text { Brosur yang menunjukkan bahwa Ayukawa adalah seorang arsitek } \\
\text { papan atas di Tokyo } \\
\qquad \text { SIGN 1: Signifier } 2\end{array}$ & $\begin{array}{l}\text { Kesuksesan } \\
\qquad \begin{array}{r}\text { Signified } 2\end{array}\end{array}$ & \\
\hline $\begin{array}{l}\text { Brosur yang menunjukkan bahwa } \\
\text { Ayukawa adalah seorang arsitek } \\
\text { papan atas di Tokyo }\end{array}$ & & - Saussure \\
\hline Signified 1 & & \\
\hline
\end{tabular}

Area intelektual yang menjadi denotasi maskulinitas laki-laki terlihat dari brosur yang berisi tentang seorang arsitek papan atas di Tokyo bernama Ayukawa Itsuki. Konotasi isi brosur ini adalah kesuksesan. Sementara, mitos maskulinitasnya terletak pada anggapan bahwa seorang laki-laki yang sukses pasti cerdas dan memiliki pemikiran yang logis serta rasional. Tidak dapat dipungkiri bahwa untuk dapat menjadi seorang arsitek handal, seseorang harus menempuh pendidikan yang cukup berat, memiliki pengalaman yang cukup dalam mendesain, dan mampu memuaskan orang yang menggunakan jasanya. Selain itu, juga dibutuhkan logika yang tinggi dalam berpikir untuk dapat mencapai posisi puncak; selaras dengan mitos yang menyebutkan bahwa laki-laki lebih mendahulukan logika dibanding emosi dalam berbagai tindakan (Santrock, 2003).

Selain dari yang sudah disebutkan, Ayukawa pun memperlihatkan maskulinitasnya dengan berpikir praktis. Ia menerima tawaran bantuan dari Kawana, perempuan adik kelasnya semasa SMA, untuk mewarnai gambar desainnya. Dari kejadian ini, dapat diketahui bahwa Ayukawa tidak menunjukkan maskulinitas tradisional Jepang yang cenderung ke arah superioritas, kekuasaan, dan posesif, seperti yang dikemukakan oleh Roberson (Ruspini et al., 2011). 


\section{Area Interpersonal}

Poin keenam dari konsep ini adalah area interpersonal yang meliputi berjiwa pemimpin, bertanggung jawab, mendominasi, disiplin, mandiri, dan individualis (Chafetz, 1978).

Tabel 6. Area Interpersonal

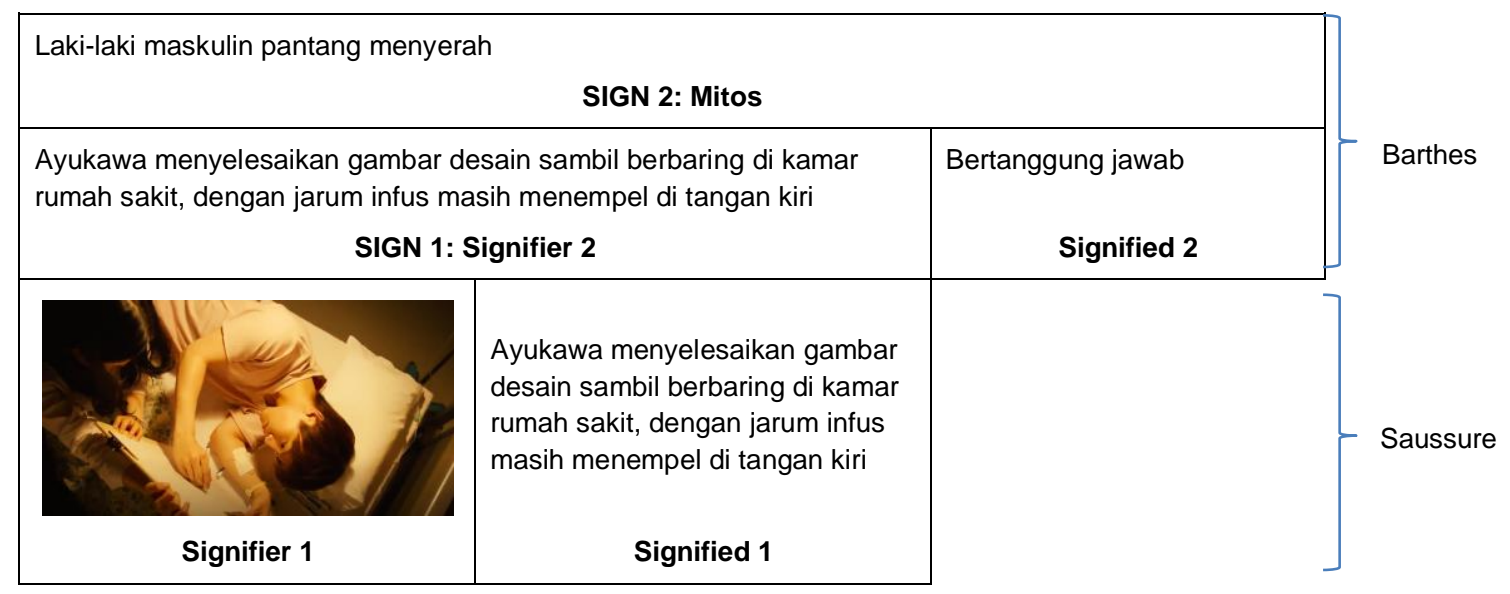

Denotasi maskulinitas laki-laki terlihat dari usaha Ayukawa menyelesaikan gambar desain tanpa mempedulikan kondisi tubuhnya yang lemah karena sakit. Konotasi maskulinitas ditunjukkan dengan bertanggung jawab untuk menyelesaikan tugas yang diberikan kepadanya. Tanggung jawab Ayukawa ini terlihat saat ia memaksakan diri menyelesaikan gambar desain pusat kegiatan masyarakat distrik Sakuragaoka meski ia sedang dirawat di rumah sakit. Ini dilakukannya mengingat tenggat waktu pengumpulan desain tersebut hanya tinggal beberapa jam. Jika desain ini terlambat diselesaikan, maka kerugian tidak hanya akan menimpa dirinya, namun juga rekan satu tim dan perusahaan tempat ia bekerja. Sementara, mitos ditunjukkan oleh sikap pantang menyerah Ayukawa dalam menyelesaikan tugas yang diberikan oleh perusahaan tempat ia bekerja, yang selaras dengan salah satu anggapan masyarakat tentang bagaimana seharusnya seorang laki-laki bersikap (Brod \& Kaufman, 1994), yang dapat dilihat di bagian pembahasan pada subbab area fungsional.

Selain itu, poin lain dalam area interpersonal yang diperlihatkan oleh Ayukawa adalah jiwa pemimpin. Dalam tugas mendesain pusat kegiatan masyarakat distrik 
Fajria Noviana, Representasi Maskulinitas Modern Laki-Laki Jepang dalam Film Perfect World Berdasarkan Semiotika Barthes

Sakuragaoka, ia dipercaya sebagai ketua tim yang membawahi beberapa rekannya yang bukan difabel. Posisi sebagai ketua tim desain memang merupakan penunjukan dari pihak perusahaan, namun ini tetap menunjukkan adanya jiwa pemimpin, mengingat pihak perusahaan tidak akan gegabah menunjuk orang yang tidak kompeten. Jiwa pemimpin ini berhubungan erat dengan rasa tanggung jawab yang dijelaskan di paragraf sebelumnya.

Satu poin lagi yang ditunjukkan oleh Ayukawa adalah sikap mandiri. Kemandirian tokoh utama ini terlihat dari usahanya untuk hidup terpisah dari orangtuanya agar tidak membebani mereka, dengan tinggal seorang diri di sebuah apartemen di Tokyo.

Maskulinitas yang diperlihatkan tokoh utama di area interpersonal ini semuanya selaras dengan konsep maskulinitas modern. Ayukawa tidak menunjukkan sikap mendominasi dan individualis; sikap yang menurut Chafetz memenuhi konsep maskulinitas tradisional. Sebaliknya, maskulinitas modern tidak terlalu peduli untuk bersikap maskulin sesuai anggapan masyarakat. Laki-laki maskulin modern tidak membutuhkan pengakuan dari pihak luar, sehingga ia bersikap sesuai dengan apa yang ia kehendaki (Schroeder, 2017).

\section{Area Karakter Personal Lainnya}

Poin ketujuh dari konsep ini adalah area karakter personal lainnya. Karakterkarakter tersebut meliputi berorientasi sukses, ambisius, bermoral, tegas, dapat dipercaya, kompetitif, penentu, bangga, egois, dan berjiwa petualang (Chafetz, 1978). Poin-poin yang disebutkan oleh Chafetz ini hanya merupakan panduan yang tidak bersifat mutlak; boleh ditambah atau dikurangi jenisnya. 
Tabel 7. Area Karakter Personal Lainnya

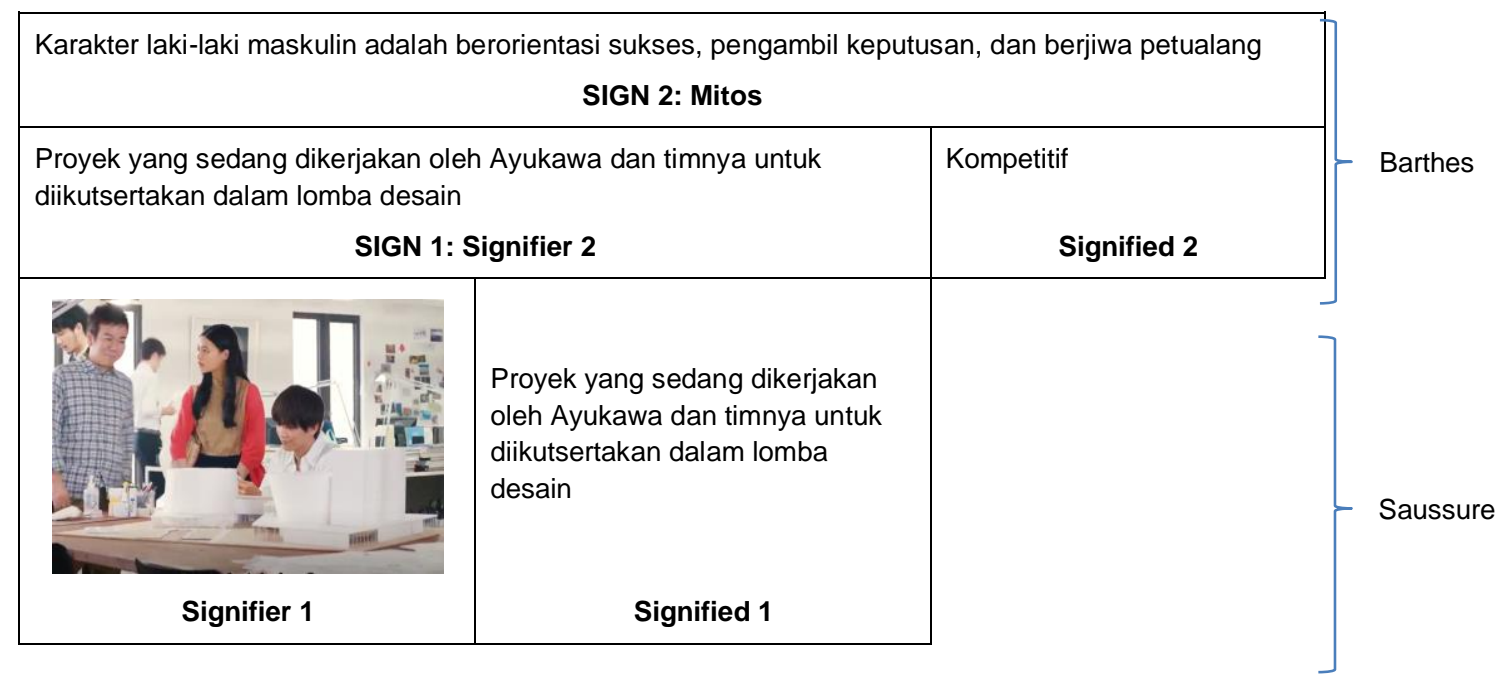

Denotasi karakter personal maskulin laki-laki terlihat dari adegan yang menunjukkan Ayukawa sedang membuat maket sebagai bagian dari proyek tim yang ia ketuai untuk diikutsertakan dalam lomba desain arsitektur. Konotasi maskulinitas dari adegan ini adalah jiwa kompetitif Ayukawa. Sementara, mitos maskulinitas karakter personal laki-laki yang ditunjukkan adalah berorientasi sukses, pengambil keputusan, dan berjiwa petualang.

Berorientasi sukses merupakan istilah lain bagi upaya menjadikan kesuksesan dalam pekerjaan sebagai tujuan utama, yang merupakan salah satu anggapan masyarakat tentang laki-laki secara tradisional (Brod \& Kaufman, 1994). Orientasi sukses Ayukawa terlihat dari bagaimana ia bekerja dengan sepenuh hati demi kesempurnaan proyeknya. Kemudian, pengambil keputusan ditunjukkan oleh posisinya sebagai ketua tim. Sementara, berjiwa petualang dapat diketahui dari keinginannya untuk ikut serta dalam lomba desain. Jiwa petualang dalam hal ini tidak dibatasi hanya pada petualangan secara fisik di alam terbuka, namun juga petualangan mental dengan berkompetisi, mencoba, atau bahkan menciptakan sesuatu yang baru, dan lain-lain.

Konotasi mengenai jiwa kompetitif Ayukawa yang termasuk dalam area karakter personal lainnya berdasarkan pendapat Chafetz (1978) ini bertentangan dengan maskulinitas modern yang diusung oleh kaum milenial. Mereka justru tidak ingin berkompetisi hanya untuk meraih status kosong karena seorang laki-laki maskulin tahu 
Fajria Noviana, Representasi Maskulinitas Modern Laki-Laki Jepang dalam Film Perfect World Berdasarkan Semiotika Barthes

persis nilai dirinya, sehingga ia tidak perlu menjatuhkan atau menyingkirkan orang lain melalui sebuah kompetisi (Schroeder, 2017). Hal ini pun bertentangan dengan pendapat Brod dan Kaufman tentang pentingnya mendapat penghormatan dari orang lain atas kesuksesan yang diperoleh seorang laki-laki maskulin (1994), yang bagi kaum milenial identik dengan status kosong.

\section{SIMPULAN}

Kondisi fisik Ayukawa sebagai seorang difabel tidak terlalu berpengaruh dalam penilaian maskulinitasnya sesuai dengan standar yang dikemukakan oleh Chafetz, dengan dukungan konsep maskulinitas tradisional dari beberapa ahli. Secara fisik, ia tetap mampu melakukan aktifitas secara mandiri layaknya laki-laki dewasa pada umumnya yang tidak memiliki keterbatasan fisik. Secara psikis, terdapat satu area dalam konsep maskulinitas tradisional yang diwakili oleh Chafetz yang sama sekali tidak terpenuhi, yaitu area emosional. Tidak terpenuhinya area ini dilatarbelakangi oleh sikap-sikap masyarakat terhadap Ayukawa sebagai seorang difabel. Meskipun demikian, dalam konsep maskulinitas modern hal ini tidak dipermasalahkan.

Dari ketujuh area yang menjadi dasar penilaian maskulinitas menurut Chafetz, hanya area fungsional dari tokoh utama yang murni menunjukkan maskulinitas tradisional. Sebaliknya, area emosionalnya murni menunjukkan maskulinitas modern. Dengan demikian dapat dikatakan bahwa tokoh utama benar-benar merepresentasikan laki-laki (difabel) dalam dunia nyata, yang umumnya berada dalam persimpangan antara maskulinitas tradisional dan modern.

Sebagai penutup, dapat dikatakan bahwa ketidaktetapan konsep maskulinitas sangat dipengaruhi oleh masyarakat pendukung tempat konsep tersebut dilahirkan dan perkembangan zaman. Seorang laki-laki difabel dapat tetap dikatakan maskulin, baik secara tradisional maupun modern, sepanjang sebagian besar poin penilaian maskulinitasnya masih terpenuhi. Sebaliknya, seorang laki-laki tanpa keterbatasan fisik dapat dikatakan tidak maskulin jika ia tidak dapat memenuhi poin penilaian maskulinitasnya. 


\section{REFERENSI}

Amalia, M. (2020). Representasi Maskulinitas Laki-Laki Difabel Dalam Film Paafekuto Waarudo: Kajian Semiotika Roland Barthes. Universitas Diponegoro. Retrieved from http://eprints.undip.ac.id/81631/1/Skripsifull_Maya_Amalia_ 2020.pdf

Brod, H., \& Kaufman, M. (1994). Theorizing Masculinities. California: SAGE Publications Ltd.

Budiman, K. (2011). Semiotika Visual: Konsep, Isu, dan Problem Ikonisitas. Yogyakarta: Jalasutra.

Chafetz, J. S. (1978). Masculine, Feminine or Human?: An Overview of the Sociology of the Gender Roles. Illinois: F. E. Peacock Publishers.

Connell, R. W., \& Messerschmidt, J. W. (2005). Hegemonic Masculinity: Rethinking the Concept. Gender and Society, 19(6), 829-859. https://doi.org/10.1177/ 0891243205278639

Demartoto, A. (2010). Konsep Maskulinitas dari Jaman ke Jaman dan Citranya Dalam Media. Retrieved March 28, 2021, from https://argyo.staff.uns.ac.id/ files/2010/08/maskulinitas-ind1.pdf

DiDonato, M. D., \& Berenbaum, S. A. (2011). The Benefits and Drawbacks of Gender Typing: How Different Dimensions are Related to Psychological Adjustment. Archives of Sexual Behavior, 40(2), 457-463.

Fakih, M. (2013). Analisis Gender dan Transformasi Sosial. Yogyakarta: Pustaka Pelajar.

Huggins, M. (2012). "Manufactured" Masculinity. Journal of Sport History, 39(1), 147-156. Retrieved from https://www.jstor.org/stable/10.5406/jsporthistory. 39.1.147

McLelland, M. (2003). Men and Masculinities in Contemporary Japan: Dislocating the Salaryman Doxa (Book Review). Intersections: Gender, History and Culture in the Asian Context, (9). Retrieved from http://intersections.anu.edu.au/ issue9/mclelland_review.html

Noviana, F., \& Wulandari, R. (2017). Maskulinitas dan Femininitas dalam Anime Kimi no Na Wa: Kajian Respon Pemirsa. Kiryoku, 1(4), 10-19.

Poedjianto, S. A. (2014). Representasi Maskulinitas Laki-laki Infertil Dalam Film Test Pack Karya Ninit Yunita (Universitas Airlangga). Universitas Airlangga. 
Fajria Noviana, Representasi Maskulinitas Modern Laki-Laki Jepang dalam Film Perfect World Berdasarkan Semiotika Barthes

Retrieved from http://repository.unair.ac.id/28771/2/FULLTEXT.pdf

Rathus, S. A., Nevid, J. S., \& Fichner-Rathus, L. (2014). Human Sexuality in a World of Diversity. New Jersey: Pearson Education, Inc.

Ruspini, E., Hearn, J., Pease, B., \& Pringle, K. (2011). Men and Masculinities Around the World. In Men and Masculinities Around the World. New York: Palgrave MacMillan. https://doi.org/10.1057/9780230338005

Santrock, J. W. (2003). Adolescence: Perkembangan Remaja. Jakarta: Erlangga.

Schroeder, J. (2017). 7 Reasons Why Millennial Men are Reinventing Masculinity. Forbes. Retrieved from https://www.forbes.com/sites/julesschroeder/ 2017/10/12/the-evolved-man-7-reasons-why-millennial-men-are-reinventingmasculinity/?sh=1935513e597c

Siegel, K., \& Meunier, É. (2019). Traditional Sex and Gender Stereotypes in the Relationships of Non-Disclosing Behaviorally Bisexual Men. Arch Sex Behav, 48(1), 333-345. https://doi.org/10.1007/s10508-018-1226-3

Sobur, A. (2016). Semiotika Komunikasi. Bandung: PT Remaja Rosdakarya.

Yusuf, M. Y. (2015). Sastra dan Difabel: Menilik Citra Difabel Dalam Novel Biola Tak Berdawai dari Sudut Pandang Sosiologi Sastra Ian Watt. Inklusi: Journal of Disability Studies, 2(1), 21. https://doi.org/10.14421/ijds.020102 